\title{
Residual effect of organics and direct effect of mineral nitrogen on rice (Oryza sativa L.) in two different textural soils
}

\author{
Manivannan R.* \\ Department of Soil Science and Agricultural Chemistry, Faculty of Agriculture, Annamalai \\ University, Annamalainagar-608002 (Tamil Nadu), India \\ M.V. Sriramachandrasekharan \\ Department of Soil Science and Agricultural Chemistry, Faculty of Agriculture, Annamalai \\ University, Annamalainagar-608002 (Tamil Nadu), India

\section{P. Senthilvalavan} \\ Department of Soil Science and Agricultural Chemistry, Faculty of Agriculture, Annamalai \\ University, Annamalainagar-608002 (Tamil Nadu), India

\section{Ravikumar} \\ Department of Agronomy, Faculty of Agriculture, Annamalai University, Annamalainagar- \\ 608002 (Tamil Nadu), India \\ *Corresponding email: rengamanivannan@gmail.com
}

\section{Article Info}

https://doi.org/10.31018/ jans.v13i1.2558

Received: February 6, 2021

Revised: March 8, 2021

Accepted: March 12. 2021

\section{How to Cite}

Manivannan, R. et al. (2021). Residual effect of organics and direct effect of mineral nitrogen on rice (Oryza sativa L.) in two different textural soils. Journal of Applied and Natural Science, 13(1): 352 - 356. https://doi.org/10.31018/jans.v13i1.2558

\begin{abstract}
Nitrogen through organics and inorganics application is an alternate to maintain soil health and crop productivity in the rice cropping system. With this background, field experiments were conducted in farmer's field at Kuttalam during 2012-2013, 2013-14 to evaluate residual organics and mineral nitrogen $(100 \% \mathrm{~N})$ on growth parameters and yield of rice (Oryza sativa) in sandy clay loam and clay loam soil. The treatments consisted of residual organics viz., composted coir pith (CCP), green manures (GM), sugarcane trash compost (STC), vermicompost (VC), poultry manure (PM) and FYM applied $(100 \% \mathrm{~N})$ and a combination of above residual organics with urea@50\%N besides 100\% recommended dose of nitrogen (RDN) and control. The results revealed that residual organics and urea recorded higher growth parameters like plant height, chlorophyll content, leaf area index ( $\mathrm{LAI}$ ), crop growth rate (CGR), relative growth rate(RGR), net assimilation rate(NAR), No. of tillers/hill compared to their individual addition. The growth parameters were more under residual PM in combination with mineral nitrogen in both the soils. Residual PM + fertilizer nitrogen $(100 \% \mathrm{~N})$ recorded highest grain $\left(4485,4693 \mathrm{~kg} \mathrm{ha}^{-1}\right)$ and straw yield $\left(6984,5897 \mathrm{~kg} \mathrm{ha}^{-1}\right)$ in clay loam and sandy clay loam soils, respectively. The lowest grain(3292, $\left.2993 \mathrm{~kg} \mathrm{ha}^{-1}\right)$ and straw yield $\left(4998,4003 \mathrm{~kg} \mathrm{ha}^{-1}\right) \mathrm{were}$ recorded in residual $\mathrm{GM}+$ fertilizer $(100 \% \mathrm{~N})$ in both soils. Among organics alone, residual $\mathrm{PM}(100 \% \mathrm{~N})$ registered highest grain yield $\left(4025,4048 \mathrm{~kg} \mathrm{ha}^{-1}\right)$ in both soils. It can be concluded that the application of poultry manure alone or in combination with $\mathrm{N}$ fertilizers enhanced the growth and improved soil health.
\end{abstract}

Keywords: Growth parameters, Mineral nitrogen, Residual organics, Rice, Yield

\section{INTRODUCTION}

Rice (Oryza sativa. $L$ ) is one of the most important cereal crops to satisfy the food requirement of the global population. India ranks first in the rice production area (45 million hectares) and second in rice production(117 million tonnes) after China(Indiastat, 2019). Nitrogen is one of the most crucial elements that is required for the growth and development of rice plants. It is involved in photosynthesis; a principal constituent of chlorophyll, enzymes, proteins and vitamins assists in the production and use of carbohydrates and is required for the energy reactions taking place within the plants (Sara et al., 2013). Intensive agriculture involving exhaustive high yielding varieties of rice has led to the heavy withdrawal of nutrients from the soil. Imbalanced and indiscriminate use of chemical fertilizers has resulted in deterioration of soil health (John et al., 2001). Despite the past gains in rice production through chemical fertilizers, recent observations of stagnant or declining yields 
have raised concerns about the long term sustainability of crop production (Khan et al., 2010). The negative impacts of chemical fertilizers coupled with escalating prices have led to growing interests in the use of organic fertilizers as a source of nutrients. Organic farming of rice increase the nutrient values of the product and reduce pesticide residues within it and allows the higher price of the crop in market (Rekha and Prasad, 2006). Poultry manure (PM) has been reported to supply $P$ more readily to plants than other organic sources (Garg and Bahla, 2008). and also PM increased soil pH, organic carbon content, available $\mathrm{P}$, exch. cations and micronutrients reduced exchangeable $\mathrm{Al}$ and $\mathrm{Fe}$ contents and bulk density(Uwah et al., 2011 and 2012). In addition, organic manures can also generate a positive residual effect that should be taken into account when planning the next crop (Eghball et al., 2004). Nutrients from organic manures (animal manures and crop residues) are released more slowly and are stored for a longer time in the soil, thereby ensuring a long residual effect ( Amanullah and Khalid, 2016; Senthilvalavan and Ravichandran, 2020). With this background, the present study was conducted to study the residual effect of organics and the direct effect of mineral $\mathrm{N}$ in rice (Oryza sativa) in clay loam and sandy clay loam soils.

\section{MATERIALS AND METHODS}

Field experiments were conducted in farmer's field at Kuttalam, Tamil Nadu in two different textured soils (sandy clay loam and clay loam) during 2012-2013, 2013-2014 in rabi and summer season to study the residual effect of organics and direct effect of mineral nitrogen on growth parameters and yield in rice $(O$. sativa) cultivation. The experimental soil was sandy clay loam (Typic Ustifluvents) and clay loam (Typic Haplusterts), $\mathrm{pH}(6.79,8.19)$, EC $(0.31,0.36)$, available nitrogen $\left(226.2,227.9 \mathrm{~kg} \mathrm{ha}^{-1}\right)$, available phosphorus (14.1, $\left.14.9 \mathrm{~kg} \mathrm{ha}^{-1}\right)$, available potassium $\left(345.7,316.7 \mathrm{~kg} \mathrm{ha}^{-1}\right)$ and organic carbon $\left(6.10,6.20 \mathrm{~g} \mathrm{~kg}^{-1}\right)$. The experiment was laid out in randomized block design and replicated thrice. A short duration rice variety cv. ADT 38 was chosen for both soils. After harvesting the rice crop, the field was prepared to fine tilth with the spade without disturbing the individual plots. The same number of 42 plots of equal size $\left(5^{\prime} 4 \mathrm{~m}=20 \mathrm{~m} 2\right)$ were used to test the residual effect of organics on the second crop by retaining the layout intact. The rice crop did not receive any organics, but it received the recommended dose of fertilizer nitrogen (100\%). 150:50:50 $\mathrm{kg} \mathrm{N}, \mathrm{P} 2 \mathrm{O} 5$ and $\mathrm{K}_{2} \mathrm{O}$ ha-1. All the treatments received phosphorus and potassium uniformly except absolute control, through superphosphate and muriate of potash. The entire dose of $\mathrm{P}_{2} \mathrm{O}_{5}$ was applied basally before transplanting. Efforts were taken to maintain a water level of 2.5 and $5 \mathrm{~cm}$ in the early and later stages of the crop growth period, respectively. Irrigation was withheld 10 days before harvesting. Experiment consisted of $\mathrm{T}_{1}$ - Absolute control, $\mathrm{T}_{2}$-Composted coir pith (CCP- $100 \% \mathrm{~N}), \mathrm{T}_{3}$-Green manure (GM-100\% N), $\mathrm{T}_{4}$ Sugarcane trash compost(STC-100\%N), $\mathrm{T}_{5^{-}}$Vermicompost (VC-100\% N), T6-Poultry Manure (PM-100\%N), $\mathrm{T}_{7}$ - Farmyard Manure (FYM-100\%N), T - CCP ( 50\% N) + Urea $(50 \% \mathrm{~N}), \mathrm{T}_{9^{-}} \mathrm{GM}(50 \% \mathrm{~N})+$ Urea $(50 \% \mathrm{~N}), \mathrm{T}_{10^{-}}$ STC $(50 \% N)+$ Urea $(50 \% N), \mathrm{T}_{11}-\mathrm{VC}(50 \% \mathrm{~N})+$ Urea $(50 \% \mathrm{~N}), \mathrm{T}_{12}-\mathrm{PM}(50 \% \mathrm{~N})+$ Urea $(50 \% \mathrm{~N}), \mathrm{T}_{13}-\mathrm{FYM}$ $(50 \% \mathrm{~N})+$ Urea $(50 \% \mathrm{~N}), \mathrm{T}_{14}-\operatorname{RDF}(120: 60: 60 \mathrm{~N}$, $\left.\mathrm{P}_{2} \mathrm{O} 5, \mathrm{~K}_{2} \mathrm{O} \mathrm{Kg} \mathrm{ha}{ }^{-1}\right)$. The $\mathrm{N}$ content in different organics include CCP (1.06\%), GM (1.90\%), STC (0.45\%), VC $(1.80 \%)$, PM $(2.15 \%)$ and FYM $(0.60 \%)$. All necessary management practices were carried out as per standard recommendation for rice crop. Biometric observations viz., plant height $(\mathrm{cm})$, no of tillers/hill, chlorophyll content(mg/100 g), CGR $\left(\mathrm{gm}^{2} \mathrm{~d}^{-1}\right), \operatorname{RGR}\left(\mathrm{mg} \mathrm{g}^{-1} \mathrm{~d}^{-1}\right)$ and NAR $\left(\mathrm{g} \mathrm{dm}^{2} \mathrm{~d}^{-1}\right)$, grain $\left(\mathrm{kg} \mathrm{ha}^{-1}\right)$ and straw yield $\left(\mathrm{kg} \mathrm{ha}^{-1}\right)$ were recorded. The percent increase over control in grain and straw yield was calculated.

\section{RESULTS AND DISCUSSION}

\section{Growth and physiological parameters}

Residual effect of organics alone or direct fertilizer nitrogen alone or integration of residual organics and fertilizer nitrogen on growth parameters over control significantly $(p=0.05 \%)$ increased in both sandy clay loam and clay loam soil (Table 1 and 2). The highest growth of parameters viz., plant height $(94.2,92.1 \mathrm{~cm})$, no. of tillers/hill (12.52, 12.97), chlorophyll content(2.89,2.89), $\operatorname{CGR}\left(11.42,10.88 \mathrm{gm}^{2} \mathrm{~d}^{-1}\right), \operatorname{RGR}\left(32.2,34.7 \mathrm{mg} \mathrm{g}^{-1} \mathrm{~d}^{-1}\right)$ and $\operatorname{NAR}\left(1.23,1.89 \mathrm{~g} \mathrm{dm}^{2} \mathrm{~d}^{-1}\right)$ were recorded in residual $P M+$ fertilizer nitrogen $\left(T_{12}\right)$ in both soils. This may be due to enhanced growth characteristics resulting in increased photosynthetic activity, which resulted in better growth rate and yield in Typic Paleoudult-(Sandy loam) in the Maize-soybean cropping system, as reported by Almaz and Martini (2020). The improvement in the growth due to improved physiological processes in plant height might be due to enhanced supply of nutrients from poultry manure and chemical fertilizers in sandy clay loam in finger millet and Groundnut cropping system (Prashantha et al., 2019).

\section{Grain and straw yield}

Residual effect of organics alone or direct fertilizer nitrogen alone or integration of residual organics and fertilizer nitrogen on grain and straw yield over control significantly $(p=0.05 \%)$ increased in both sandy clay loam and clay loam soil (Table 3 ). The highest grain yield (4485, $\left.4693 \mathrm{~kg} \mathrm{ha}^{-1}\right)$ and straw yield $\left(6984,5897 \mathrm{~kg} \mathrm{ha}^{-}\right.$ ${ }^{1}$ ) were noticed in residual poultry manure + fertilizer nitrogen $(100 \% \mathrm{~N})$ in both soils. Poultry manure incorporation in the main crop resulted in transformation and 
Manivannan, R. et al. / J. Appl. \& Nat. Sci. 13(1): 352 - 356 (2021)

Table 1. Residual effect of organics and direct effect of mineral nitrogen on growth parameters of rice (O. sativa).

\begin{tabular}{|c|c|c|c|c|c|c|}
\hline \multirow{2}{*}{$\begin{array}{l}\text { Soils } \\
\text { Treatments }\end{array}$} & \multicolumn{3}{|c|}{ Clay loam } & \multicolumn{3}{|c|}{ Sandy clay loam } \\
\hline & $\begin{array}{l}\text { Plant } \\
\text { height } \\
(\mathrm{cm})\end{array}$ & $\begin{array}{l}\text { No. tillers/ } \\
\text { hill }\end{array}$ & $\begin{array}{l}\text { Chlorophyll } \\
\text { content } \\
(\mathrm{mg} / 100 \mathrm{~g})\end{array}$ & $\begin{array}{l}\text { Plant } \\
\text { height } \\
(\mathrm{cm})\end{array}$ & $\begin{array}{l}\text { No. tillers/ } \\
\text { hill }\end{array}$ & $\begin{array}{l}\text { Chlorophyll } \\
\text { content } \\
(\mathrm{mg} / 100 \mathrm{~g})\end{array}$ \\
\hline $\mathrm{T}_{1}$ - Absolute control & 72.4 & 6.72 & 2.20 & 71.8 & 5.87 & 2.20 \\
\hline $\mathrm{T}_{2}-(\mathrm{CCP}-100 \% \mathrm{~N})$ & 75.9 & 7.53 & 2.32 & 75.0 & 6.86 & 2.29 \\
\hline $\mathrm{T}_{3}-(\mathrm{GM}-100 \% \mathrm{~N})$ & 74.2 & 7.09 & 2.29 & 74.2 & 6.30 & 2.25 \\
\hline $\mathrm{T}_{4}-(\mathrm{CST}-100 \% \mathrm{~N})$ & 76.8 & 8.32 & 2.37 & 75.6 & 7.93 & 2.32 \\
\hline $\mathrm{T}_{5}-(\mathrm{VC}-100 \% \mathrm{~N})$ & 80.7 & 9.08 & 2.43 & 83.2 & 8.38 & 2.37 \\
\hline $\mathrm{T}_{6}-(\mathrm{PM}-100 \% \mathrm{~N})$ & 82.1 & 9.51 & 2.46 & 84.8 & 8.83 & 2.40 \\
\hline $\mathrm{T}_{7}-(\mathrm{FYM}-100 \% \mathrm{~N})$ & 78.3 & 8.83 & 2.40 & 82.1 & 8.14 & 2.36 \\
\hline $\mathrm{T}_{8}-\mathrm{CCP}+$ Urea $(100 \% \mathrm{~N})$ & 87.6 & 10.47 & 2.56 & 86.1 & 9.73 & 2.53 \\
\hline $\mathrm{T}_{9}-\mathrm{GM}+$ Urea $(100 \% \mathrm{~N})$ & 83.4 & 9.12 & 2.49 & 85.2 & 9.17 & 2.49 \\
\hline $\mathrm{T}_{10}-\mathrm{CST}+$ Urea $(100 \% \mathrm{~N})$ & 91.3 & 10.91 & 2.62 & 87.2 & 10.79 & 2.60 \\
\hline $\mathrm{T}_{11}-\mathrm{VC}+$ Urea $(100 \% \mathrm{~N})$ & 93.6 & 12.06 & 2.80 & 91.3 & 12.32 & 2.80 \\
\hline $\mathrm{T}_{12}-\mathrm{PM}+$ Urea $(100 \% \mathrm{~N})$ & 94.2 & 12.52 & 2.89 & 92.1 & 12.97 & 2.89 \\
\hline $\mathrm{T}_{13}-\mathrm{FYM}+$ Urea $(100 \% \mathrm{~N})$ & 92.7 & 11.67 & 2.09 & 90.9 & 12.02 & 2.75 \\
\hline $\begin{array}{l}\mathrm{T}_{14}-\mathrm{RDF}\left(150: 50: 50 \mathrm{~N}, \mathrm{P}_{2} \mathrm{O}_{5} \mathrm{~K}_{2} \mathrm{O}\right. \\
\left.\mathrm{kg} \mathrm{ha}^{-1}\right)\end{array}$ & 92.0 & 11.24 & 2.69 & 90.1 & 11.83 & 2.69 \\
\hline C.D @ 5\% & 0.47 & 0.05 & 0.06 & 0.27 & 0.04 & 0.02 \\
\hline
\end{tabular}

Table 2. Residual effect of organics and direct effect of mineral nitrogen on physiological parameters of rice (O. sativa).

\begin{tabular}{|c|c|c|c|c|c|c|}
\hline Soils & & Clay loam & & & andy clay lo & \\
\hline Treatments & $\begin{array}{l}\text { CGR } \\
\left(\mathrm{gm}^{2} \mathrm{~d}^{-1}\right)\end{array}$ & $\begin{array}{l}\text { RGR } \\
\left(\mathrm{mg} \mathrm{g}^{-1} \mathrm{~d}^{-1}\right)\end{array}$ & $\begin{array}{l}\text { NAR } \\
\left(g_{\left.\mathrm{dm}^{2} \mathrm{~d}^{-1}\right)}\right.\end{array}$ & $\begin{array}{l}\text { CGR } \\
\left(\mathrm{gm}^{2} \mathrm{~d}^{-1}\right)\end{array}$ & $\begin{array}{l}\text { RGR } \\
\left(\mathrm{mg} \mathrm{g}^{-1} \mathrm{~d}^{-1}\right)\end{array}$ & $\begin{array}{l}\text { NAR } \\
\left(\mathrm{g} \mathrm{dm}^{2} \mathrm{~d}^{-1}\right)\end{array}$ \\
\hline $\mathrm{T}_{1}$ - Absolute control & 7.42 & 23.2 & 0.95 & 6.43 & 23.1 & 1.21 \\
\hline $\mathrm{T}_{2}-(\mathrm{CCP}-100 \% \mathrm{~N})$ & 8.10 & 25.7 & 1.01 & 7.91 & 26.8 & 1.43 \\
\hline $\mathrm{T}_{3}-(\mathrm{GM}-100 \% \mathrm{~N})$ & 7.83 & 25.0 & 0.98 & 7.13 & 26.0 & 1.40 \\
\hline $\mathrm{T}_{4^{-}}(\mathrm{CST}-100 \% \mathrm{~N})$ & 8.42 & 26.4 & 1.02 & 8.12 & 27.0 & 1.47 \\
\hline $\mathrm{T}_{5}-(\mathrm{VC}-100 \% \mathrm{~N})$ & 8.92 & 27.4 & 1.06 & 8.774 & 28.3 & 1.59 \\
\hline $\mathbf{T}_{6}-(\mathrm{PM}-100 \% \mathrm{~N})$ & 9.06 & 27.9 & 1.08 & 8.91 & 29.2 & 1.65 \\
\hline $\mathbf{T}_{7^{-}}(\mathrm{FYM}-100 \% \mathrm{~N})$ & 8.72 & 26.8 & 1.04 & 8.52 & 28.0 & 1.50 \\
\hline $\mathrm{T}_{8}-\mathrm{CCP}+$ Urea $(100 \% \mathrm{~N})$ & 9.74 & 28.7 & 1.14 & 9.43 & 31.2 & 1.70 \\
\hline $\mathrm{T}_{9}-\mathrm{GM}+$ Urea $(100 \% \mathrm{~N})$ & 9.42 & 28.5 & 1.10 & 9.02 & 30.6 & 1.64 \\
\hline $\mathbf{T}_{10^{-}}$CST+ Urea $(100 \% \mathrm{~N})$ & 10.13 & 29.2 & 1.16 & 9.63 & 32.0 & 1.74 \\
\hline $\mathbf{T}_{11}-\mathrm{VC}+$ Urea $(100 \% \mathrm{~N})$ & 11.14 & 31.9 & 1.21 & 10.48 & 34.0 & 1.82 \\
\hline $\mathrm{T}_{12^{-}} \mathrm{PM}+$ Urea $(100 \% \mathrm{~N})$ & 11.42 & 32.2 & 1.23 & 10.88 & 34.7 & 1.89 \\
\hline $\mathrm{T}_{13^{-}} \mathrm{FYM}+$ Urea $(100 \% \mathrm{~N})$ & 10.80 & 31.4 & 1.20 & 10.02 & 33.2 & 1.79 \\
\hline $\begin{array}{l}\mathrm{T}_{14^{-}}-\mathrm{RDF}\left(150: 50: 50 \mathrm{~N}, \mathrm{P}_{2} \mathrm{O}_{5} \mathrm{~K}_{2} \mathrm{O}\right. \\
\mathrm{kg} \mathrm{ha-1})\end{array}$ & 10.61 & 31.1 & 1.18 & 9.77 & 32.8 & 1.78 \\
\hline C.D @ 5\% & 0.05 & 0.43 & 0.06 & 0.28 & 0.46 & 0.03 \\
\hline
\end{tabular}

CGR-Crop growth rate; RGR- Relative growth rate; NAR- Net assimilation rate

modified the mechanics and dynamics of nutrient mobilization, resulting in increased grain yield in succeeding rice crop. It also resulted in the part of nutrients remained unutilized by the main crop is expected to help growth and development of succeeding crop. Present results corroborate with those of Singh et al. (2004). i.e. in addition to unutilized nutrient usage and advantages associated with improved physical properties of sandy clay loam in the rice-lentil cropping system had more residual benefits. Further, in the present study, results where organics alone used, i.e. the residual poultry manure + fertilizer nitrogen, resulted in increased grain yield (4025, $\left.4048 \mathrm{~kg} \mathrm{ha}^{-1}\right)$ and straw yield (6132, 4945 $\mathrm{kg} \mathrm{ha}^{-1}$ ) in clay loam and sandy clay loam soils, respectively. On the other hand, the superiority of poultry manure was attributed to its slow and steady decomposition, which probably released the nutrients slowly and in higher quantity compared to other organic materials, which ultimately resulted in a superior grain and straw yield. Similar findings were reported by Mohammadre- 
Manivannan, R. et al. / J. Appl. \& Nat. Sci. 13(1): 352 - 356 (2021)

Table 3. Residual effect of organics and direct effect of mineral nitrogen on yield of rice (O. sativa).

\begin{tabular}{|c|c|c|c|c|c|c|c|c|}
\hline \multirow{2}{*}{$\begin{array}{l}\text { Soils } \\
\text { Treatments }\end{array}$} & \multicolumn{4}{|c|}{ Clay loam } & \multicolumn{4}{|c|}{ Sandy clay loam } \\
\hline & $\begin{array}{l}\text { Grain } \\
\text { yield } \\
\text { (kg/ } \\
\text { ha) }\end{array}$ & $\begin{array}{l}\text { \% in- } \\
\text { crease } \\
\text { over } \\
\text { control }\end{array}$ & $\begin{array}{l}\text { Straw } \\
\text { yield } \\
\text { (kg/ha) }\end{array}$ & $\begin{array}{l}\% \text { in- } \\
\text { crease } \\
\text { over } \\
\text { control }\end{array}$ & $\begin{array}{l}\text { Grain } \\
\text { yield } \\
\text { (kg/ha) }\end{array}$ & $\begin{array}{l}\text { \% in- } \\
\text { crease } \\
\text { over con- } \\
\text { trol }\end{array}$ & $\begin{array}{l}\text { Straw } \\
\text { yield } \\
\text { (kg/ha) }\end{array}$ & $\begin{array}{l}\% \text { in- } \\
\text { crease } \\
\text { over } \\
\text { control }\end{array}$ \\
\hline $\mathrm{T}_{1}$ - Absolute control & 3292 & - & 4998 & - & 2993 & - & 4003 & - \\
\hline $\mathbf{T}_{2}-(\mathrm{CCP}-100 \% \mathrm{~N})$ & 3826 & 16.2 & 5800 & 16.0 & 3827 & 27.8 & 4593 & 14.7 \\
\hline $\mathrm{T}_{3}-(\mathrm{GM}-100 \% \mathrm{~N})$ & 3731 & 13.3 & 5720 & 14.2 & 3682 & 23.0 & 4510 & 12.6 \\
\hline $\left.\mathbf{T}_{4}-\mathrm{CST}-100 \% \mathrm{~N}\right)$ & 3987 & 21.1 & 5840 & 16.8 & 3912 & 30.7 & 4719 & 17.8 \\
\hline $\mathrm{T}_{5}-(\mathrm{VC}-100 \% \mathrm{~N})$ & 4018 & 22.0 & 6108 & 22.2 & 4031 & 34.6 & 4879 & 21.8 \\
\hline $\mathrm{T}_{6}-(\mathrm{PM}-100 \% \mathrm{~N})$ & 4025 & 22.3 & 6132 & 22.6 & 4048 & 35.2 & 4945 & 23.5 \\
\hline $\mathbf{T}_{7}-(\mathrm{FYM}-100 \% \mathrm{~N})$ & 4010 & 21.8 & 5982 & 19.6 & 3929 & 31.3 & 4740 & 18.4 \\
\hline $\mathbf{T}_{8^{-}}$CCP + Urea $(100 \% \mathrm{~N})$ & 4120 & 25.1 & 6657 & 33.2 & 4132 & 38.0 & 5298 & 32.3 \\
\hline $\mathbf{T}_{9}-\mathrm{GM}+$ Urea $(100 \% \mathrm{~N})^{\prime}$ & 4098 & 24.4 & 6242 & 30.1 & 4099 & 36.9 & 5120 & 27.9 \\
\hline $\mathbf{T}_{10^{-}} \mathrm{CST}+$ Urea $(100 \% \mathrm{~N})$ & 4133 & 25.5 & 6798 & 36.0 & 4283 & 43.1 & 5380 & 34.4 \\
\hline $\mathbf{T}_{11}-\mathrm{VC}+$ Urea $(100 \% \mathrm{~N})$ & 4386 & 33.2 & 6960 & 39.2 & 4527 & 51.2 & 5823 & 45.4 \\
\hline $\mathbf{T}_{12-}-\mathrm{PM}+$ Urea $(100 \% \mathrm{~N})$ & 4485 & 36.2 & 6984 & 39.7 & 4693 & 56.7 & 5897 & 47.3 \\
\hline $\mathbf{T}_{13}-\mathrm{FYM}+$ Urea $(100 \% \mathrm{~N})$ & 4235 & 23.6 & 6840 & 36.8 & 4492 & 50.0 & 5781 & 44.4 \\
\hline $\begin{array}{l}\mathrm{T}_{14-}-\mathrm{RDF}(150: 50: 50 \mathrm{~N} \\
\left.\mathrm{P}_{2} \mathrm{O}_{5} \mathrm{~K}_{2} \mathrm{O} \mathrm{kg} \mathrm{ha}^{-1}\right)\end{array}$ & 4310 & 31.0 & 6832 & 36.7 & 4387 & 46.5 & 5692 & 42.2 \\
\hline C.D @ $5 \%$ & 10.54 & & 12.55 & & 17.29 & & 19.93 & \\
\hline
\end{tabular}

za Davari et al. (2012) for the rice-wheat- mungbean cropping system.

\section{Conclusion}

Based on the results, it can be concluded that application of residual poultry manure alone or in combination with fertilizer nitrogen $(100 \% N)$ significantly $(p=0.05 \%)$ improved the growth parameters and yield of rice $(O$. sativa) over control in both soils. Among the different organics applied, the poultry manure recorded higher residual effect $(22 \%, 35.2 \%)$ in clay loam and sandy clay loam, respectively, over control. Therefore, the substitution of $\mathrm{N}$ fertilizer with poultry manure is recommended to improve the yield of subsequent rice crop.

\section{Conflict of interest}

The authors declare that they have no conflict of interest.

\section{REFERENCES}

1. Amanullah, and Khalid, S. (2016). Phenology, growth and biomass yield response of maize (Zea mays L.) to integrated use of animal manures and phosphorus application with and without phosphate solubilizing bacteria. $J$ Microb. Biochem. Technol., 7, 439-444. doi: 10.4172/19485948.1000251.

2. Almaz Meseret Gezahegn and Martini, M.Y. (2020). Effects of residual organic manure and supplemental inorganic fertilizers on performance of subsequent Maize crop and soil chemical properties. International Journal of Research Studies in Agricultural Sciences, (IJRSAS), 6(1), 1-9.

3. Eghball B, Ginting D, and Gilley J.E. (2004). Residual effects of manure and compost applications on corn pro- duction and soil properties. Agron. J., 96, 442-447.

4. Garg S. and Bahla (2008). Phosphorus availability to maize as influenced by organic manures and fertilizers $P$ associated phosphatase activity in soils. Bioresource Tech. 99(13), 5773- 5777.

5. Indiastat (2019). Socio-economic statistics information about India, Retrieved from https:// www.indiastat.com

6. John, P.S., George, M and Jacob, R. (2001). Nutrient mining in agroclimatic zones of kerala. Fertilizer News. 46, 45-52, 55-57.

7. Khan, N. I. , A.U. Malik, F. Umer and M.I. Bodla. (2010). Effect of tillage and farm yard manure on physical properties of soil. International Research Journal of Plant Science, 1(4), 75-82.

8. Mohammadreza Davari., Shri Niwas Sharma., and Mohammad Mirzakhani (2012). Residual influence of organic materials crop residues and biofertilizers on performance of succeeding mung bean in an organic rice- based cropping system International Journal of Recycling of Organic Wastes in Agriculture. 1(14), 121-128.

9. Prashantha, G. M, Prakash, S. S, Umesha, S, Chikkaramappa, C, Subbarayappa, T and Ramamurthy V. (2019). Direct and residual effect of zinc and and boron on yield and yield attributes of finger millet- ground nut cropping system. Int. J. Pure App. Biosci. 7(1), 124-134.

10. Rekha, S.N. and Prasad. R. N. (2006). Pesticide residue in organic and conventional food- Risk Analysis" Journal of Chemical and Health Safety.13, 12-19.

11. Sara, S, M. Morad and Reza, (2013). Effects of seed inoculation by rhizobium strains on chlorophyll content and protein percentage in common bean cultivars (Phaseolus vulgaris L.). International Journal of Biosciences 3, 1-8.

12. Senthilvalavan, $P$ and Ravichandran. M. (2020). Post harvest soil fertility status of rice-black gram cropping system in Typic haplusterts influenced by integrated nutrient management and crop cultivation techniques. Plant Archives, 20 (1), $2644-2649$.

13. Singh, S.K., Varma, S. C. and Singh, R. (2004). Residual effect of organic and inorganic sources of nutrients in low- 
land rice on succeeding lentil. Indian J. Agric. Res. 38(2), 121-125.

14. Uwah D.F, Eneji A.E, and Eshiet U.J. (2011). Organic and mineral fertilizers effects on the performance of sweet maize (Zea mays L. saccharata Strut.) in south eastern rainforest zone of Nigeria. Int'l J. Agric. Sci., 3(1), 54-61.

15. Uwah D.F, Ukoha G.O, and lyango J. (2012). Okra performance and soil and water conservation as influenced by poultry manure and organic mulch amendments. J. Food, Agric and Environ, (1), 748- 754. 